\title{
Gender-Based Affirmative Policy for Female Migrant Workers
}

\author{
Isnaini Rodiyah ${ }^{1}$, Jusuf Irianto ${ }^{2}$ \\ isnaini@umsida.ac.id ${ }^{1}$ \\ Fakultas Ilmu Sosial dan Ilmu Politik \\ Program Study Administrasi Publik \\ Universitas Muhammadiyah Sidoarjo ${ }^{1}$ \\ jusuf.irianto@ fisip.unair.ac.id ${ }^{2}$ \\ Fakultas Ilmu Sosial dan Ilmu Politik \\ Program Study Administrasi Negara \\ Universitas Airlangga Surabaya
}

\begin{abstract}
This research purposes to map the problem that faced by Indonesian migrant workers (TKI) and analyze the affirmative policy gender-based. This research used qualitative descriptive approach and located in East Java. The data obtained from deeply interview with selected informant based on consideration of research and results study from the document. Data analysis used interactive model by Miles and Hubermann. Based on data from National Agency for Placement and Protection of Indonesian Workers (BNP2TKI) and Migrant Care in 2016, numbers of female migrant workers (TKW) are very high, reach $70 \%$ in total from migrant workers. The findings show that the female migrant workers (TKW) problems in pre-placement are unsuitable shelter, malnutrition, and harassment during medical check up. Most problems precisely at the placement step, those are rights violation of underpay salary, work overtime, restriction of entitlements absent, restriction of social interaction (communicating and socializing), ignored opinions, sexual harassment, stereotype, violence, even become victims of human trafficking and drugs. The findings also shows that protection policy for female migrant workers (TKW) as affirmative is very needed to make the action on subordination, marginalization, stereotype, violence protection, and resolve the work overtime.
\end{abstract}

Key Words: affirmative policy, gender, social protection, and female migrant workers.

\section{Introduction}

In the macroeconomic level mentioned that one solution that can solve the problem in the development of liberal feminism is to start by stopping the marginalization of women by fighting for changes in laws and regulations that allow for women to have the same access to and control of jobs and economic rewards [3]. In other condition, the problem of employment and community welfare has not yet been able to be overcome by the government; therefore working abroad into Indonesian migrant workers (TKI) became the logical choice. The main reason for Indonesian migrant workers to go abroad according to [7] is looking for better jobs for higher income, so that after they go home they can become entrepreneurs. Beside that, the success stories of their friends make them willing to go abroad to work.

The phenomenon of working abroad has always increased, recorded in 2014 reaching 429,882 people [4], where the majority of these are mostly female migrant workers (TKW). The high rate of migration, not only limited to economic issues but also related to the issue of gender relations, labor regulations and issues of migrant workers who are vulnerable to exploitation so that they are vulnerable to becoming victims of trafficking [6]. The existence 
of women as Indonesian migrant workers (TKI) abroad is also inseparable from the issue of gender equality and justice, even now it is still one of the issues that are heavily discussed by various parties. Gender equality is defined as a gap between the state and position of women and men in community, especially as a woman has limited opportunities compared to men in actively participate in various programs and other activities in the community in the economic, socio-cultural, educational, organization in institutions, and so on [11]. In the work field, there is one area of discrimination occurring for female workers. The forms of discrimination against women in employment or industrial relations is very broad the spectrum, since someone hasn't worked until they finish the work. This resulted; women suffer gender inequality in employment relationships [2].

The role of women as wives and housewives cannot be separated from the obligations and responsibilities of cooking activities, caring for children and other activities related to household affairs, because of poor economic conditions, women also demanded to become the backbone of the family to strengthen the family economy. This phenomenon is called gender inequality namely the dual role of women, this role become hardly, when women have to migrate to try their luck abroad become migrant workers who are relatively vulnerable to labor problems and vulnerable to being victims of women trafficking. The problem of migrant workers is vulnerable to several rights violations, those are: salary deduction, underpay salary, overtime working, unpaid wages, detained passport and restrictions on communicating and socializing [6]. Forms of gender inequality manifests in the form of discrimination such as marginalization, subordination, stereotyping, violence and workload [3].

Seeing these conditions, then the government should be able to provide protection and be able to accommodate the needs of migrant workers, one of them is the issue of gender equality for female migrant workers. For that matter, Further studies need to be carried out on the implementation of affirmative social protection policies for female migrant workers in East Java.

\section{Theoretical Framework}

\subsection{Gender}

Gender is a concept that is constructed socially and culturally, to distinguish between non-physical characteristics between men and women [3]. Another meaning is based on East Java Governor Regulation No. 66 of 2013 stated that gender is a concept that refers to the roles and responsibilities of men and women that occur as a result and can be in the form of social conditions and community.

Gender can be translated as "social gender", is a term or concept that describes the differences between men and women in a socio-cultural way. Gender has social, cultural and psychological significance. Gender is a differentiating concept between women and men who refer to social relations and distinguish between functions and roles between men. The difference in function and role between men and women is not only determined because of biological or natural differences, but it is distinguished according to position, function and each role in various fields of community life and dynamics.

Discussion of gender issues to this day still raises the pros and cons for several reasons including differences in social factors, perspective, properties, functions, sociological and others. In short, the inherent differences in gender issues lead to gaps in the issue of gender equality and justice.

Gender equality is a condition where women and men enjoy equal status and have the same conditions to realize fully human rights and their potential for development in all areas of life [8]. Gender equality means the equality of conditions for men and women to get opportunities and their rights as human beings, so that they are able to play a role and participate in political, law, economic, socio-cultural, educational and defense and national 
security activities (hankamnas), and similarities in development. Gender equality also includes eliminating discrimination and structural injustice for both men and women [10].

Meanwhile, definition of gender justice is a fair condition for women and men through cultural processes and policies that eliminate barriers for women and the role of men [8]. Gender justice according to [10] is a condition and equitable treatment of women and men. Gender justice occurs when opportunities for both men and women to pursue various interests, careers, lifestyles and specific needs of women or men. Gender justice is achieved when special efforts and policies are made to provide equal opportunities for men and women. Therefore, all women and men have equal opportunities to develop all their skills and talents.

\subsection{Affirmative Policy}

Affirmative policy is a policy that is taken to ensure that certain groups (gender or profession) have equal opportunities with other groups in the same field. Affirmative policy can also be interpreted as a policy that gives privileges to certain groups. The essence of affirmative policy is to eliminate prejudice, exclusion and neglect that can lead to discrimination. Therefore, Affirmative policy is a proactive and progressive step to eliminate discrimination based on individual merits, not manipulation of stereotyped perceptions. Affirmative policy provides equal opportunities and equal treatment for anyone with equal opportunity principles. Implementation of this policy is expected to be able to involve a group of people, who were originally excluded and underrepresented in the public domain without any restrictions or only based on individual qualifications [1].

\section{Method}

Research on the affirmative policy of social protection of female migrant workers in East Java is a qualitative study with a descriptive method. The focus of the research that will be discussed is about mapping the problems faced by TKW and observing affirmative policy issues concerning gender injustice that afflict TKW seen in the concept of marginalization, subordination, stereotype, violence, and workload from pre-placement, placement until after placement stages. The data collection technique in this research used the Indeep interview method and documentation of news relating to the issues of gender inequality of female migrant workers as well as documentation of legislation as well as previous research on the problem of implementing affirmative social protection policies for female migrant workers. The analysis technique used to summarize the results of research is an interactive model of Miles and Huberman starting from condensation phase of data, data collection, data presentation and the last one is the conclusion [5].

\section{Result and Discussion}

Indonesia is a country that has a large number of Indonesian migrant workers. Based on data from National Agency for Placement and Protection of Indonesian Workers (BNP2TKI) in 2016 as much as 234.451 people, and increase become 261.820 people in 2017. The following data are the amount of migrant workers according to each Province in 2016-2017.

Table 1. Amount of Indonesian migrant workers according to each Province in 2016-2017

\begin{tabular}{|c|c|c|c|c|}
\cline { 2 - 5 } \multicolumn{1}{c|}{2016} & \multicolumn{2}{c|}{2017} \\
\hline No. & PROVINCE & AMOUNT & PROVINCE & AMOUNT \\
\hline 1 & West Java & 51.047 & East Java & 63.498 \\
\hline
\end{tabular}




\begin{tabular}{|c|c|c|c|c|}
\hline 2 & Central Java & 49.512 & Central Java & 54.737 \\
\hline 3 & East Java & 43.135 & West Java & 50.756 \\
\hline 4 & West Nusa Tenggara & 40.415 & West Nusa Tenggara & 34.975 \\
\hline 5 & Lampung & 16.049 & North Sumatera & 17.109 \\
\hline 6 & North Sumatera & 14.137 & Lampung & 15.327 \\
\hline 7 & Bali & 3.258 & Bali & 4.872 \\
\hline 8 & Banten & 2.684 & East Kalimantan & 2.758 \\
\hline 9 & East Nusa Tenggara & 2.357 & Banten & 2.315 \\
\hline \multirow[t]{2}{*}{10} & West Kalimantan & 1.834 & South Sumatera & 2.103 \\
\hline & Others & 10.023 & Others & 13.370 \\
\hline & Total & 234.451 & & 261.820 \\
\hline
\end{tabular}

The number of Indonesian migrant workers from East Java Province in 2016 was 43.135 people, placing East Java as a province as the third largest contributor to Indonesian migrant workers after West Java (51.047) and Central Java (49.512). The number of Indonesian migrant workers from East Java in 2017 increased to 63.498 people, thus placing East Java as a province as the first largest contributor to Indonesian migrant workers. To ease the explanation of the data about the number of Indonesian migrant workers in 2016-2017 can be seen in Figure 1 as follows.

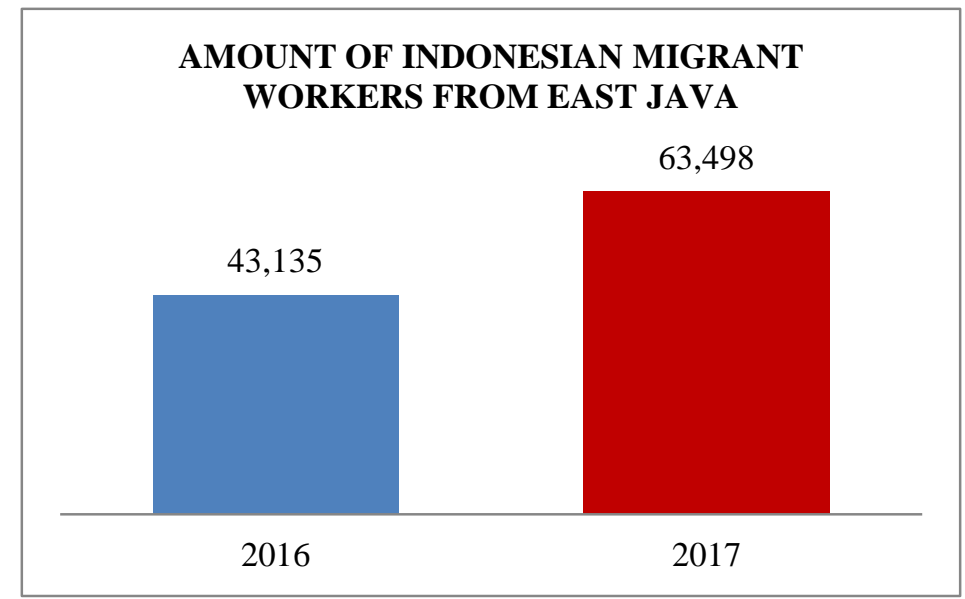

Figure 1. The Graphics of Amount of Indonesian Migrant Workers from East Java in 2016-2017

According to the graphics above, can be state that the number of Indonesian migrant workers from East Java in 2016 is 43.135 people and in 2017 is 63.498 people. During the period 2016-2017 the number of Indonesian migrant workers from East Java significantly increase around 20.363 people or $47,21 \%$. To know the district/city in East Java that give contributor to increasing number of Indonesian migrant workers from East Java during period 2016-2017 can be seen in Figure 2 as follows. 


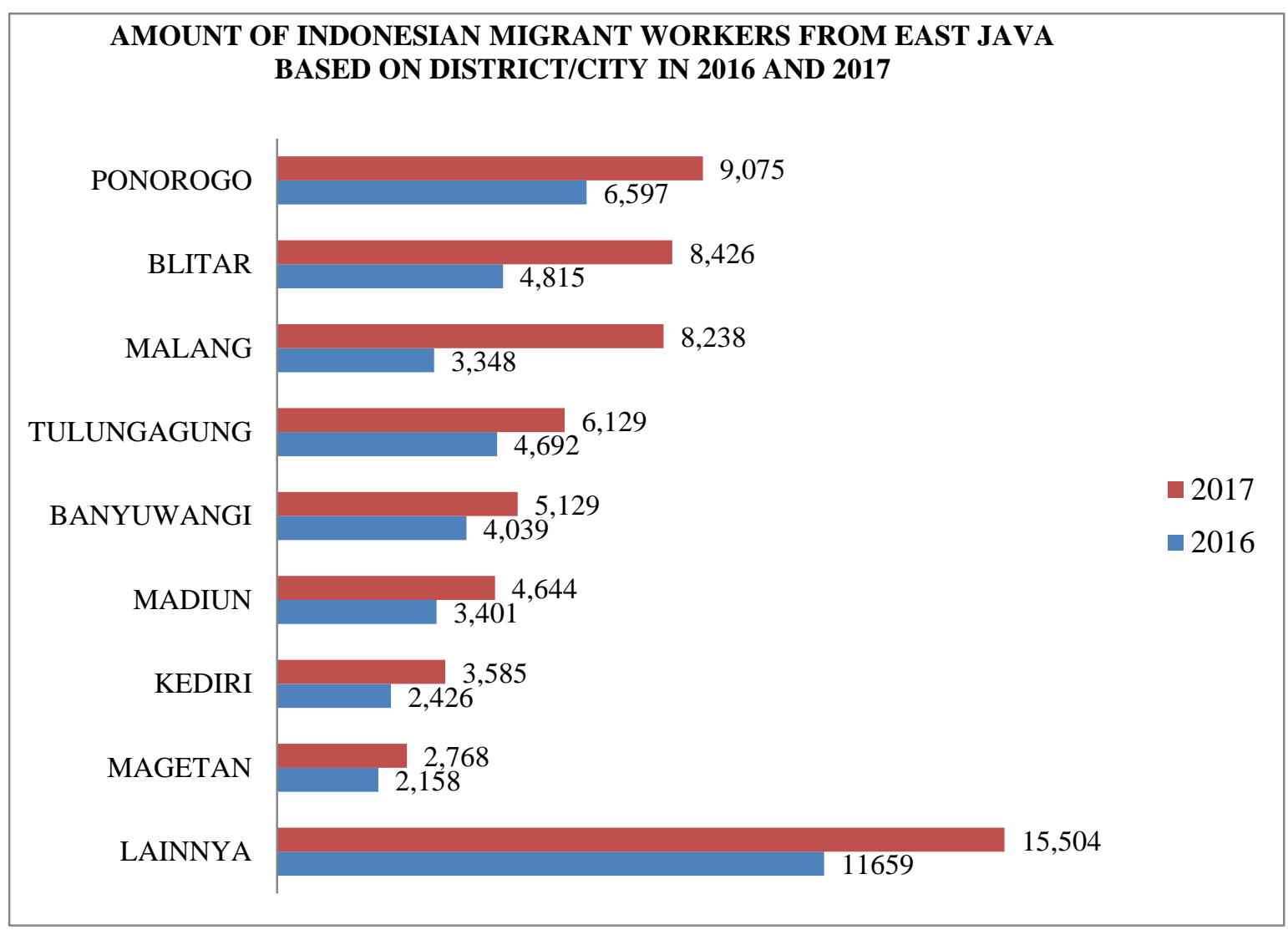

Figure 2. The Graphics of Comparison of Indonesian Migrant Workers from East Java based on District/City in 2016-2017

Based on figure 2, it can be known that district of Ponorogo, Blitar, Malang, Tulungagung, Banyuwangi, Madiun, Kediri, and Magetan all of them have increased the number of Indonesian migrant workers during 2016-2017. The most significant increase of the number of Indonesian migrant workers are in Blitar around 3.611 people $(74,99 \%)$ and Malang around 4.890 people $(146,06 \%)$. This shows that there is an increase in number of Indonesian migrant workers from East Java during 2016-2017 because in common the number of Indonesian migrant workers in each district/city significantly increased.

From those numbers of Indonesian migrant workers from East Java, 54\% to $62 \%$ consist of female migrant workers. Even from the other sources, Migrant Care predicts the number of Indonesian migrant workers around 6.5 million people, which $70 \%$ are women [9]. An increase the number of Indonesian migrant workers should be balanced by increasing the quality of the protection of female migrant workers' rights that is increasingly evident. But in reality based on research findings, it is known that the implementation of social protection policies for migrant workers in reality still does not reflect the realization of gender justice.

Forms of violations of the rights of TKW that often occur in the pre-placement stage, that is when in a shelter (lack of decent shelter, rough treatment, debriefing of minimal competency material, as well as the implementation of competency and medical tests that are less stringent) and when there is still extortion in the departure terminal carried out by individuals. 
The problem of gender injustice towards TKW mostly occurs at the placement stage, this is due to the placement of Indonesian workers dominated by the private sector (PPTKIS). Upon arrival at the airport in destination country, TKIs are already in the hands of the agencies who then hand them over to users. The pattern of delivery and placement of TKI using $\mathrm{P}$ to $\mathrm{P}$ (Private to Private) management cause TKI are not more like commodities merchandise. The absence of a policy capable of intervening with the private sector (PPTKIS) in determining the cost structure, so that it has an impact on the high cost structure that TKI must pay to PPTKIS. Moreover, there has been no firmness from the government through a policy that is intended for employers or even PPTKIS who hold an Indonesian migrant workers passport and visa detention. This detention of passports and visas has triggered the problems of social protection of TKI. From this study it was revealed that the passport and visa were apparently not held by TKI. The document is held or controlled by an employer or agent in the destination country with the intention of guaranteeing that TKI complete the task in accordance with the contract until completion. Thus, TKI become very bound and have no choice and freedom because they do not hold official documents. As a result, if there are problems Indonesian migrant workers can not do much and have no choice except to survive in the miserable workplace. Often the options listed in the employment agreement may change at any time, especially in the placement and type of work that is likely to disserve TKI. There are no other choices for TKI except accept these changes even though not in accordance with the original contract and does not fit well with the early interest and provision of competence. Generally, TKWs who work abroad have experienced problems from the beginning with the support of low competence. Agents and employers often complain about the quality of TKI, so they tend to choose workers from other countries that are more qualified. As a result, agents and employers in destination countries often treat TKIs arbitrarily. The implementation of social protection at this stage of placement is further weakened by the low quality of TKI itself.

Final stage or full placement, violations of gender justice that occur are TKI who often experience neglect when they arrive in their country (Indonesia). The pick-up is done by PPTKIS more often due to the persistence of financial affairs that has not been completed between PPTKIS with TKI. Often the PPTKIS overrides the assignment of full placement assistance under the pretext that the contract between PPTKIS and TKI is limited to preplacement up to placement only.

Based on the research findings as described above, then the government must make affirmative policies to support existing regulations, namely Law No. 18 of 2017 concerning social protection for Indonesian Migrant Workers. The current policy has not been in detail and concretely regulates gender equality, so that many migrant workers' rights are violated. In pre-placement stage, Affirmative policies for TKW can be done by strengthening the monitoring and supervision system of the Private TKI Placement Implementation agencies (PPTKIS) as a labor agency that is obliged to accommodate and provide provision of skills before leaving for the country of placement. Besides that, Affirmative policies at the preplacement stage need to be carried out through the dissemination of BNP2TKI's 24-hour complaint center service especially to TKW candidates. This effort is carried out as a complaint service for prospective migrant workers who feel disadvantaged by the individuals of the recruitment agency (PPTKIS).

The placement stage is the most frequent stage of acts of gender injustice, especially the form of violence that is often experienced by TKW. The solution that can be put forward is to create gender-based affirmative policies by strengthening coordination with networks (networking). The labor attaché abroad is a government representative in the placement country. The performance of the labor attaches must continue to be improved to reduce the number of cases of gender injustice by providing advocacy for TKW, legalization of employment agreements or employment contracts and finding good employment opportunities 
for TKW candidates. Moreover, coordinating with the Indonesian Embassy (KBRI) in the country the placement of TKW must be increased. The involvement of the Indonesian Embassy (KBRI) in the protection of Indonesian migrant workers (TKI) abroad has a huge contribution. Data supply from BNP2TKI to KBRI can be an important tool in monitoring work placements of TKW. But these efforts are not optimal if they do not involve the local government in the form of $G$ to $G$ (Government to Government) cooperation. Policy on the Protection of Indonesianm Migrant Workers have limitations that can not be applied abroad, because each country has its own sovereignty. Therefore, strengthening of networks must also be done with local countries to jointly create gender-based affirmative policies to address violations rights of TKW. The collaboration between the Indonesian government and the local government will facilitate labor attaches and the Indonesian Embassy to provide protection to migrant workers in particular.

While for the full placement stage, gender-based affirmative policy as a safeguard for TKW when arrived in airport, that is through strengthening the function of service posts for the arrival of Indonesian migrant workers (TKI) at the airport as government representatives. Besides monitoring the returning activities of Indonesian migrant workers (TKI) at the airport, Service posts also need to provide assistance specifically to TKW regarding return to their hometowns.

\section{Conclusion}

Based on the analysis performed can be concluded, that the current policy is still not optimal in protecting rights of TKW, forms of gender injustice still occur at all stages, especially at the placement stage. Protection policy for TKW as affirmative it is very necessary to take action in subordination, marginalization, stereotypes, protection of acts of violence, and overcoming the workload that transcends boundaries. Especially for the placement stage, implementation of protection policies for TKW must involve networking, including the labor attaché and the Indonesian Embassy as representatives of the government, and the local government that has sovereignty in the country. This collaboration is established in the form of $G$ to $G$ (Government to Government) collaboration.

\section{References}

[1] Alhumami, A.: Mitos Kebijakan Afirmatif. Harian Kompas 5 Februari (2009)

[2] Chusniatun., Kuswardhani dan J. Suwandi.: Peran Ganda Dan Pengembangan Karier Guru-Guru Perempuan Di Sekolah Muhhamadiyah Kota Surakarta. E-journal Universitas Muhammadiyah Surakarta, Hal. 1-14 (2015)

[3] Fakih, M.: Analisis Gender \& Transformasi Sosial Edisi 15. Yogyakarta: Insist Press (2016)

[4] Habibullah, A. Juhari, L. Sandra.: Kebijakan Perlindungan Sosial Untuk Pekerja Migran Bermasalah. Sosio Konsepsia Vol. 5 No. 2, Hal. 66-77 (2016)

[5] Huberman A. Michael and Miles Mettew B.: Qualitative Data Analysis. Sage publication (2014)

[6] Legal Resouces Center untuk Keadilan Jender dan Hak Asasi Manusia (LRC-KJHAM).: Keterkaitan Antara Gender, Migrasi, Labour Dan Trafficking. Feminist Participatory Action Research (FPAR) (2010)

[7] Mafruhah Izza, Sarsito Totok, and Gravitiani Evi.: The Welfare of the Indonesian Migrant Workers (TKI) in the Land of a Malay Nation: A Socio-Economic Analysis. Southeast Asian Journal of Social and Political Issues, Vol. 1, No. 2 (2012)

[8] Puspitawati, H.: Gender dan Keluarga: Konsep dan Realita di Indonesia. PT. IPB Press Bogor (2013)

[9] Rahayu Ninik.: Indonesian Migrant Worker Policies and the Vulnerability of Women Migrant Workers to Becoming Trafficking Victims: an Overview of Recent Legislation. Journal of Southeast Asian Human Rights, Vol.1 No. 2. pp. 159-172 (2017)

[10] Soetjipto Ani , Wardani Sri Budi Eko, dan Panjaitan Yolanda.: Pengarusutamaan Gender Di Parlemen: Studi Terhadap DPR Dan DPD Periode 2004-2009, UNDP Indonesia: Jakarta (2010) 
[11] Widayani, N. Made., dan S. Hartati.: Kesetaraan dan Keadilan Gender Dalam Pandangan Perempuan Bali: Studi Fenomologis Terhadap Penulis Perempuan Bali. Jurnal Psikologi Undip Vol. 13 No. 2 Oktober 2014, Hal. 149-162 (2015)

\section{Government Regulation:}

East Java Governor Regulation No. 66 of 2013

Law No. 18 of 2017 concerning the Protection of Indonesian Migrant Workers

BNP2TKI. 2017. Data on the Placement and Protection of Indonesian Migrant Workers in 2016. Center for Information Research and Development 